\title{
EFEKTIVITAS PENERAPAN MODEL PEMBELAJARAN POE (PREDICT-OBSERVE-EXPLAIN) UNTUK MENINGKATKAN PENGUASAAN KONSEP IPA
}

\section{THE EFFECTIVENESS OF APPLYING THE POE (PREDICT-OBSERVE-EXPLAIN) LEARNING MODEL TO IMPROVE CONCEPT OF SCIENCE}

\author{
Siti Fatimatuzzohrah, A. Wahab Jufri dan I Wayan Mertha \\ Program Studi Pendidikan Biologi FKIP Universitas Mataram, Mataram, Indonesia \\ Email: sitifatimatuzzohrah27@gmail.com
}

Diterima: 20 Januari 2020. Disetujui: 07 Februari 2020. Dipublikasikan: 30 September 2020

\begin{abstract}
Abstrak: Penguasaaan konsep IPA siswa SMPN 2 Kayangan masih tergolong rendah. Rendahnya penguasaan konsep IPA siswa disebabkan karena pembelajaran IPA cenderung masih berpusat pada guru (teacher centered learning). Solusinya adalah menggunakan model pembelajaran POE (predict-observe-explain) yang mampu meningkatkan penguasaan konsep siswa. Penelitian ini bertujuan untuk mengetahui efektivitas penerapan model pembelajaran POE (predict-observe-explain) dalam meningkatan penguasaan konsep IPA siswa kelas VII SMPN 2 Kayangan. Desain penelitian yang digunakan adalah Non Equivalence Pretest-Postest Control Group Design. Populasi penelitian adalah seluruh siswa kelas VII SMPN 2 Kayangan tahun 2019. Pengambilan sampel dilakukan dengan Purposive Sampling sehingga didapatkan kelas $\mathrm{VII}_{1}$ sebagai kelas kontrol dan kelas $\mathrm{VII}_{2}$ sebagai kelas eksperimen. Instrumen yang digunakan untuk memperoleh data yaitu tes penguasaan konsep berupa soal pilihan ganda. Model pembelajaran POE dan konvensional kedua-duanya dapat efektif meningkatkan penguasaan konsep IPA kelas VII di SMPN 2 Kayangan, akan tetapi peningkatan nilai rata-rata N-gain untuk kelas eksperimen yang menggunakan model POE lebih tinggi (0.8) dibandingkan dengan kelas kontrol yang menggunakan model pembelajaran konvensional (0.6).
\end{abstract}

Kata kunci: Model Pembelajaran POE, Penguasaan Konsep

\begin{abstract}
The mastery of science concept for students at SMPN 2 Kayangan are still low. The lowness is caused by science learning is centered to the teacher (teacher centered learning). The solution is used POE (predict-observeexplain) learning model who can improve the mastery concept for students. This study aim to find out the affectivity of learning model POE (predict-observe-explain) application to improve mastery of the science concept for students in class VII at SMPN 2 Kayangan. This study was designed by Non Equivalence Pretest-Posttest Control Group Design. The populations of this study were all the students in class VII at SMPN 2 Kayangan 2019. The sample was obtained by Purposive Sampling with the results are class $\mathrm{VII}_{1}$ as the control class and class $\mathrm{VII}_{2}$ as the experiment class. The instrument to collect the data was using mastery concept with multiple choice questions. POE learning model and conventional, both are effective to improve the mastery of science concept for students in class VII at SMPN 2 Kayangan, therefor the increasing of average percentage N-gain for experiment class which is using POE model are higher $(0.8)$ rather than control class which is using conventional learning model $(0.6)$.
\end{abstract}

Keywords: POE Learning Model, Mastery Concept

\section{PENDAHULUAN}

Permasalahan yang sering dihadapi dalam pembelajaran IPA adalah pembelajaran masih berlangsung dengan cara mentransfer pengetahuan dari guru kepada peserta didik dan pembelajaran IPA masih cenderung berbasis hafalan teori tidak didasarkan pada pengalaman langsung peserta didik, sehingga kemampuan peserta didik dalam memahami konsep masih rendah. Padahal bila mengacu pada Permendiknas No.22 tahun 2006, dalam pembelajaran sains sebaiknya dilaksanakan secara inkuiri ilmiah untuk menumbuhkan kemampuan berpikir, bekerja dan bersikap ilmiah serta mengkomunikasikannya sebagai aspek penting dalam kecakapan hidup. Proses Pembelajaran IPA yang belum sepenuhnya menerapkan prinsip inkuiri ilmiah, menyebabkan partisipasi aktif peserta didik dalam pembelajaran kurang. Kurangnya partisipasi peserta didik menyebabkan penguasaan konsep masih rendah dan kurang optimal.

Maesyarah dkk. [5] menyatakan bahwa rendahnya penguasaan konsep disebabkan oleh terdapat banyak istilah dalam bahasa latin yarg sulit dipahami, kurangnya minat siswa dalam membaca dan menelaah buku untuk memahami konsep yang benar dan kurangnya minat siswa maupun keterbatasan siswa dalam menggunakan media 
J. Pijar MIPA, Vol. 15 No.4, September 2020: 351-356 DOI: 10.29303/jpm.v15i4.1653

internet guna mengikuti perkembangan ilmu pengetahuan. Untuk dapat menguasai konsep, siswa harus dapat menghubungkan materi yang telah dibaca dari buku teks atau yang didengar dari penjelasan guru dengan pengetahuan yang telah diketahui sebelumnya [2]. Pentingnya penguasaan konsep dalam pembelajaran biologi menuntut proses pembelajaran sains di sekolah tidak semata-mata menyiapkan siswa untuk melanjutkan ke jenjang pendidikan yang lebih tinggi tapi yang lebih penting adalah menyiapkan siswa untuk : (1) Mampu memecahkan masalah yang dihadapi dalam kehidupan sehari-hari dengan menggunakan konsepkonsep sains yang telah dipelajari; (2) Mampu mengambil keputusan yang tepat untuk menggunakan konsep-konsep ilmiah; dan (3) Mempunyai sikap ilmiah dalam memecahkan masalah yang dihadapi sehingga memungkinkan mereka untuk berpikir dan bertindak secara ilmiah [6].

Berdasarkan data yang diperoleh dari guru mata pelajaran IPA di SMPN 2 Kayangan rata-rata nilai siswa kurang dari KKM yaitu 53. Hal ini membuktikan bahwa penguasaaan konsep IPA di SMPN 2 Kayangan masih sangat rendah. Rendahnya penguasaan konsep IPA siswa disebabkan karena pembelajaran IPA cenderung masih berpusat pada guru (teacher centered learning). Pembelajaran IPA di SMPN 2 Kecamatan Kayangan lebih dominan menggunakan metode konvensional, meskipun terkadang guru sudah menggunakan cara membentuk kelompok diskusi. Siswa kurang diajak untuk menggunakan pengetahuan dan kemampuan berpikirnya untuk merumuskan sendiri apa yang harus dicapai dalam pembelajaran. Penyampaian ilmu yang bersifat satu arah ini menyebabkan siswa kurang bersemangat dalam menerima pembelajaran karena siswa hanya sebagai obyek dan dibatasi kebebasannya dalam proses belajar mengajar. Kondisi siswa yang jenuh ini dapat menjadi penghambat dalam proses transfer materi antara guru dan siswa. Hal ini menyebabkan siswa kurang kreatif dalam memecahkan masalah, partisispasi rendah, kerja sama dalam kelompok tidak optimal, kegiatan belajar mengajar tidak efisien dan pada akhirnya penguasaan konsep siswa menjadi rendah.

Berkaitan dengan hal di atas, perlu diupayakan suatu bentuk pembelajaran yang mampu mengaktifkan siswa agar penyajian materi IPA menjadi lebih menarik, sehingga dapat membantu siswa mengatasi kesulitan belajar dan menghilangkan persepsi buruk siswa terhadap pelajaran IPA. Pembelajaran yang dimaksud adalah pembelajaran yang tidak hanya mampu memahami materi saja tetapi juga mempunyai kemampuan yang dapat membuat siswa aktif terlibat dalam proses belajar mengajar sehingga diharapkan mampu meningkatkan penguasaan konsep siswa.

Salah satu model pembelajaran yang dapat diterapkan adalah POE (prediction, observation, and explanation). Model POE memiliki sintaks yang terdiri atas prediksi, observasi dan menjelaskan, sehingga dengan menerapkan model ini selama pembelajaran siswa dapat aktif berpikir dan mengembangkan penguasaan konsep yang meliputi memprediksi, mengamati dan menjelaskan. Beberapa penelitian juga telah membuktikan bahwa model POE ini mampu membantu siswa lebih aktif selama proses pembelajaran terutama dalam membuktikan suatu konsep berdasarkan hasil pengamatan dan analisis yang mereka lakukan sendiri. Siswa juga menjadi lebih tertantang untuk membuktikan hasil prediksi mereka melalui serangkaian kegiatan percobaan atau observasi [9]. Joyce [4] juga menambahkan bahwa model POE ini mampu merangsang siswa untuk lebih kreatif khususnya dalam mengajukan prediksi dan menjadikan proses pembelajaran menjadi lebih menarik, karena siswa tidak hanya mendengarkan tetapi juga mengamati dan mempraktekkan langsung kegiatan yang berhubungan dengan materi pelajaran. Siswa juga memiliki kesempatan untuk membandingkan antara teori (dugaan) dengan kenyataan menggunakan model ini.

Berdasarkan hal tersebut perlu dilakukan penelitian tentang Efektivitas Penerapan Model Pembelajaran POE (Predict-Observe-Explain) untuk Meningkatkan Penguasaan Konsep IPA Siswa Kelas VII SMPN 2 Kayangan.

\section{METODE PENELITIAN}

Penelitian ini telah dilaksanakan di SMPN 2 Kayangan Kabupaten Lombok Utara Propinsi NTB pada bulan Juli sampai dengan agustus semester ganjil tahun ajaran 2019/2020. Desain penelitian yang digunakan adalah Non Equivalence PretestPostest Control Group Design. Variabel bebas penelitian ini adalah model pembelajaran POE (predict-observe-explain) dan variable terikat adalah penguasaan konsep. Populasi penelitian adalah seluruh siswa kelas VII SMPN 2 Kayangan tahun ajaran 2019/2020 yang terdiri dari kelas $\mathrm{VII}_{1}, \mathrm{VII}_{2}$ dan $\mathrm{VII}_{3}$. Sampel penelitian diambil dengan teknik purposive sampling sehingga diperoleh kelas $\mathrm{VII}_{1}$ sebagai kelas kontrol dan kelas $\mathrm{VII}_{2}$ sebagai kelas eksperimen. Instrumen yang digunakan untuk mengukur ketercapaian penguasaan konsep IPA siswa adalah tes yang berupa soal pilihan ganda. Data yang diperoleh dianalisis menggunakan uji N-Gain. 
J. Pijar MIPA, Vol. 15 No.4, September 2020: 351-356 DOI: 10.29303/jpm.v15i4.1653

\section{HASIL DAN PEMBAHASAN}

Penilain penguasaan konsep siswa bertujuan untuk mengetahui efektivitas penerapan model pembelajaran POE untuk meningkatan penguasaan konsep IPA siswa kelas VII SMPN 2 Kayangan, dimana keefektivan pembelajaran akan tampak pada kemampuan siswa dalam mencapai tujuan belajar yang telah ditetapkan. Untuk mengetahui perbedaan terhadap hasil belajar tentang penguasaan konsep pada materi klasifikasi makhluk hidup, siswa diberikan tes awal (pre-test) bertujuan untuk mengetahi penguasaan konsep awal siswa sebelum diberikannya materi tentang klasifikasi makhluk hidup, kemudian diberikan tes akhir (post-test) untuk mengetahui peningkatan penguasaan konsep. Nilai pre-test dan post-test penguasaan konsep siswa sebelum dan sesudah penggunaan model pembelajaran POE (predict-observe-explain) mengalami perbedaan. Analisis nilai pretest siswa bertujuan untuk mengetahui penguasaan konsep awal. Sedangkan analisis nilai post-test untuk mengetahui peningkatan penguasaan konsep siswa setelah menggunakan model pembelajaran POE (predict-observe-explain).

Berdasarkan Gambar 3.1 diketahui bahwa ratarata kelas eksperimen dan kelas kontrol mengalami peningkatan. Nilai rata-rata pre-test kelas eksperimen adalah 31.29 dan nilai

rata-rata post-test kelas eksperimen adalah 86.07 sedangkan nilai rata-rata pre-test kelas kontrol adalah 32.86 dan nilai rata-rata post-test kelas kontrol adalah 84.29 .

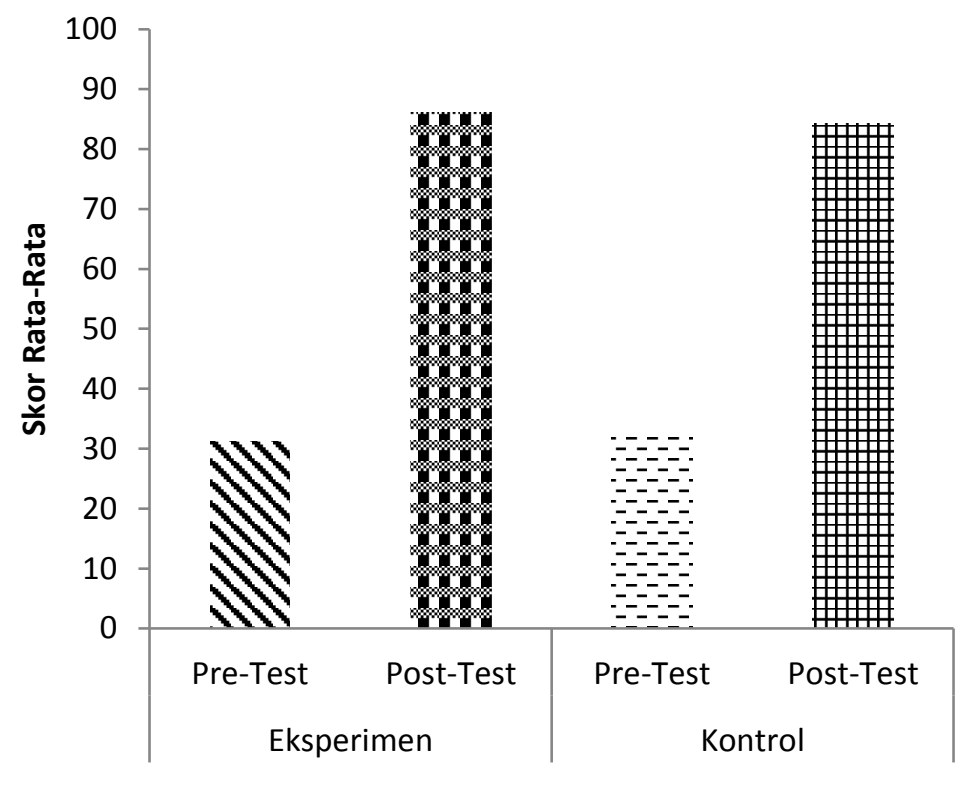

Gambar 3.1 Deskripsi Data

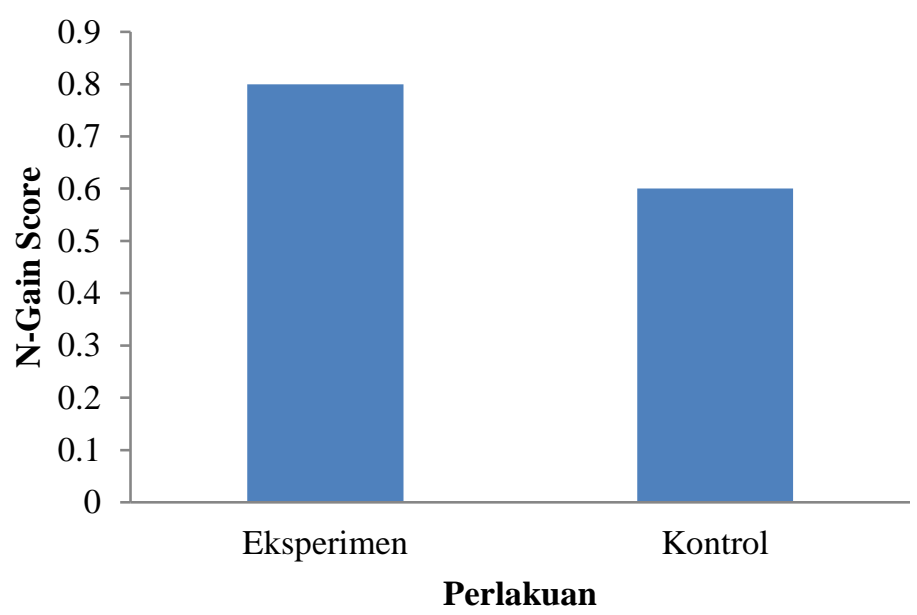

Gambar 3.2 hasil uji N-Gain score 
Berdasarkan Gambar 4.2 diketahui bahwa nilai rata-rata $\mathrm{N}$-Gain score untuk kelas eksperimen adalah 0.8 (tinggi) sedangkan nilai rata-rata $\mathrm{N}$-Gain score untuk kelas kontrol adalah 0.6 (sedang). Hal ini membuktikan bahwa nilai rata-rata $\mathrm{N}$-Gain score kelas eksperimen termasuk dalam kategori tinggi sedangkan nilai rata-rata $\mathrm{N}$-Gain score kelas kontrol termasuk dalam kategori sedang. Keefektivan model pembelajaran POE juga bisa di buktikan dengan nilai ketuntasan klasikal siswa yang mencapai $100 \%$. Hal ini membuktikan bahwa nilai tersebut melebihi $85 \%$ yang merupakan indikator keefektifan penggunaan suatu model pembelajaran. Sehingga dapat disimpulkan bahwa penggunan model pembelajaran POE efektif untuk meningkatkan penguasaan konsep IPA siswa kelas VII SMPN 2 Kayangan.

Penguasaan konsep oleh siswa tidak hanya pada mengenal sebuah konsep tetapi siswa dapat menghubungkan antara satu konsep dengan konsep lainnya dalam berbagai situasi. Penerapan pembelajaran POE (Predict-Observe-Explain) menuntut siswa yang aktif dan terlibat langsung dalam eksperimen sehingga siswa lebih mendalami konsep dengan membuat hubungan antara bagianbagian informasi yang saling terpisah untuk menjadi gambaran yang terperinci. Hal ini sejalan dengan hasil penelitian Susilawati, dkk [11] yang menyatakan bahwa siswa diberi kesempatan untuk membangun pengetahuan-pengetahuan yang ada dalam pikirannya sendiri yang diawali melalui pertanyaan-pertanyaan yang diberikan guru, merancang percobaan, melakukan percobaan, melakukan kajian pustaka dari berbagai sumber belajar kemudian menghubungkannya dengan hasil percobaannya. Melalui kegiatan-kegiatan tersebut siswa mampu menemukan konsep sendiri dengan bimbingan guru sehingga konsep tersebut akan tersimpan dalam memori jangka panjang siswa.

Siswa yang belajar dengan menggunakan model pembelajaran POE (Predict-Observe-Explain) memiliki dampak jangka panjang pada penguasaan konsep-konsep biologinya. Dengan diterapkannya model pembelajaran POE (Predict-Observe-Explain), siswa lebih tertarik pada pembelajaran yang diajarkan karena siswa mendapatkan pengalaman secara langsung serta dalam proses pembelajaran dengan model pembelajaran POE (Predict-Observe-Explain), siswa belajar dari permasalahan yang diberikan oleh guru, kemudian membuat hipotesis, mencari informasi yang berkaitan dengan permasalah tersebut melalui eksperimen untuk memperoleh data, selanjutnya mengolah data kemudian siswa dapat menarik kesimpulan mengenai masalah yang diberikan berdasarkan eksperimen. Hasil penelitian ini juga sesuai dengan penelitian yang terlebih dahulu dilakukan Oleh Puji Rahayu [10] yang menyatakan bahwa Penerapan Strategi POE (Predict-ObserveExplain) dengan metode jurnal belajar dalam pembelajaran IPA dapat meningkatkan pemahaman konsep peserta didik. Hal ini disebabkan karena seluruh rangkaian kegiatan pembelajaran dengan model POE (Predict-Observe-Explain) lebih menekankan pada aktivitas siswa secara maksimal melalui kegiatan ilmiah untuk mencari dan menemukan sendiri konsep-konsep yang dipelajari, sehingga siswa akan lebih mudah memahami konsepkonsep yang rumit dan abstrak karena disertai dengan pengalaman nyata dan terhindar dari cara-cara belajar tradisional (menghafal).

Model pembelajaran POE menekankan kepada cara belajar siswa aktif. Model ini juga memberikan makna yang baik terhadap kegiatan belajar siswa. Model pembelajaran POE ini termasuk dalam teori belajar konstruktivisme, sehingga lebih banyak menuntut keaktifan siswa dalam mendapatkan sendiri konsep-konsep pembelajaran. Sehingga tugas guru tidak lagi memberikan pengetahuan, melainkan menyiapkan situasi yang menggiring siswa untuk bertanya, mengamati, mengadakan eksperimen serta menemukan fakta dan konsep sendiri. Hal ini sesuai dengan pendapat Widyaningrum, dkk [13] yang menyatakan bahwa Model POE menjadikan siswa lebih siap saat akan praktikum karena sebelumnya siswa harus membaca teori sehingga dapat membuat prediksi yang rasional. Selain itu, siswa juga berinteraksi dengan alat dan bahan, sehingga siswa dapat menguji prediksi melalui pengamatan (observe) dan mengemukakan penjelasan tentang fenomena yang mereka hadapi (explain). Hal ini juga sejalan dengan hasil penelitian Wahyuni, dkk (2018) yang menyatakan bahwa tahapan kegiatan pembelajaran berbantuan eksperimen membantu siswa untuk mengingat dan menjelaskan konsep yang dipelajarinya dengan lebih baik. Hal ini karena siswa terlibat langsung dalam menemukan konsepnya sendiri melalui sebuah pembuktian.

Hasil tes penguasaan konsep siswa lebih tinggi pada penerapan model pembelajaran POE. Peningkatan ini disebabkan oleh penerapan model pembelajaran POE mengarahkan siswa lebih mudah memahami materi pembelajaran karena diajarkan melalui kerjasama tim atau kelompok dalam mencari informasi tentang subtopik yang diberikan oleh guru. Belajar dalam tim memungkinkan siswa lebih mengembangkan penalarannya pada tingkat yang lebih tinggi, karena pada saat diskusi terjadi pembagian peran dalam kelompok, sehingga membuat pembelajaran lebih menarik dan membantu terjadinya kerja sama antar anggota yang mengakibatkan tumbuhnya keaktifan siswa dalam pembelajaran. Hal ini sejalan dengan hasil penelitian Jannah, dkk [3] yang menyatakan bahwa kerjasama 
di antara siswa dapat memacu kreativitas serta saling melengkapi kekurangan mereka. Berbeda halnya jika soal dikerjakan secara individu. Dengan demikian model pembelajaran POE dapat mendorong keaktifan siswa untuk menggali pengetahuannya secara mandiri dalam mencari informasi pada konsep yang sedang dipelajarinya. Dalam penelitian ini juga ditemukan bahwa model pembelajaran POE dapat membentuk kemandirian siswa dalam berbagi tugas dalam kelompok untuk menyelesaikan tugas-tugas akademik yang diberikan oleh guru. Kegiatan penyelidikan yang dilakukan siswa pada penerapan model pembelajaran POE mendukung keterampilan proses kognitif berupa penguasaan konsep yang dapat diperoleh dari hasil pencarian informasi, analisis informasi, dan menyimpulkan serta pemecahan masalah dan membuat keputusan. Kegiatan diskusi kelompok dan saling berbagi pendapat dapat melahirkan perluasan dan konflik kognitif peserta didik. Penerapan model pembelajaran POE tidak hanya berguna untuk menyampaikan materi pembelajaran, tetapi hendaknya dapat melatih peserta didik untuk berpikir menggunakan struktur kognitifnya secara penuh dan terarah. model pembelajaran POE dapat digunakan guru untuk mengembangkan kreativitas siswa, baik secara perorangan maupun kelompok. Hal ini sesuai dengan pendapat Atriyanti dan Hadisaputro [1] yang menyatakan bahwa model pembelajaran POE mengajak siswa untuk sama-sama menemukan pengetahuan sendiri melalui praktikum sehingga dapat mudah diinggat. Setiap individu siswa mempunyai perbedaan pemikiran ataupun pendapat mengenai jawaban-jawaban atas prediksi ataupun hasil pengamatan yang dilakukan, sehingga siswa akan lebih aktif untuk menanggapai masalah yang ada.

Model pembelajaran POE menuntut siswa harus melakukan kegiatan prediksi terlebih dahulu. Keuntungannya adalah siswa menjadi lebih aktif karena pada kegiatan tersebut siswa harus menggunakan daya nalar dan pengetahuan yang dimiliki untuk membuat suatu ramalan dan menghubungkannya dengan pemahaman konsep yang telah didapatkan saat pembelajaran di kelas. Selain itu, pada tahap akhir yaitu explain (menjelaskan) siswa mendapatkan kesempatan penuh untuk mencurahkan segala pengetahuan yang dimiliki, menghubungkan konsep-konsep yang telah dipelajari dalam menterjemahkan hasil-hasil dari observasi yang telah dilaksanakan sebelumnya. Sehingga, pada tahap ini baik guru maupun siswa lainnya dapat memberikan penilaian dan tanggapannya terhadap penjelasan hasil-hasil eksperimentasi yang disampaikan. Pembelajaran dengan menggunakan model pembelajaran POE tidak selalu mudah diterapkan, sulitnya pengelolaan kelas ketika kegiatan eksplorasi mengakibatkan siswa seringkali menyepelekan dan bergantung kepada temannya. Penerapan model pembelajaran POE biasanya cenderung melakukan eksperimen secara berkelompok sehingga guru akan kesulitan memantau keaktifan siswa secara menyeluruh.

Temuan dalam penelitian ini memperkuat beberapa penelitian sebelumnya diantaranya penelitian yang dilakukan Nuramelia [7] yang menyatakan bahwa pembelajaran dengan menggunakan model pembelajaran POE pada konsep sistem pencernaan manusia cukup efektif dalam meningkatkan keterampilan proses dan aktivitas belajar siswa di kelas dan Rahayu [10] yang menyatakan bahwa penerapan strategi POE (PredictObserve-Explain) dengan metode jurnal belajar dalam pembelajaran IPA dapat meningkatkan pemahaman konsep peserta didik.

Gaya belajar merupakan salah satu faktor internal yang memungkinkan dapat mempengaruhi penguasaan konsep IPA peserta didik. Gaya belajar adalah kombinasi dari bagaimana seseorang menyerap kemudian mengatur dan mengolah informasi. Seseorang yang memahami gaya belajarnya sendiri akan mampu mengambil langkahlangkah penting untuk membantu dirinya belajar lebih cepat dan mudah. Demikian pula dalam mencapai tujuan pembelajaran di sekolah, diharapkan guru maupun peserta didik mampu memahami kecenderungan gaya belajar yang dimiliki. Faktor internal gaya belajar peserta didik yang tidak terakomodasi dengan baik sangat mungkin menyebabkan penerapan model pembelajaran POE dan model pembelajaran konvensional sama-sama efektif untuk meningkatkan penguasaan konsep IPA peserta didik. Dalam penelitian ini peserta didik dikatagorikan memiliki kecenderungan gaya belajar visual dan auditori. Walaupun masing-masing peserta didik belajar dengan menggunakan dua gaya belajar ini pada tahapan tertentu, tetapi kebanyakan siswa lebih cenderung pada salah satu di antara keduanya.

Gaya belajar memiliki ciri khas tersendiri. Untuk gaya belajar visual, yang memegang peranan penting adalah indera penglihatan (mata). Peserta didik yang dominan memiliki gaya belajar visual lebih nyaman belajar, apabila gurunya membawakan alat peraga/media dalam pembelajaran atau dengan langsung mengajak ke objek-objek yang berkaitan dengan konsep yang dikaji. Peserta didik dengan gaya belajar visual, sangat memperhatikan bahasa tubuh dan ekspresi wajah gurunya. Gaya belajar auditori, mengandalkan kesuksesan belajar melalui indera pendengaran (telinga). Peserta didik yang dominan memiliki gaya belajar auditori merasa nyaman belajar, apabila belajar dengan berdiskusi 
J. Pijar MIPA, Vol. 15 No.4, September 2020: 351-356 DOI: 10.29303/jpm.v15i4.1653

secara verbal dan mendengarkan apa yang dikatakan guru. Siswa yang bergaya belajar auditori, perolehan belajarnya sangat dipengaruhi oleh tone suara, pitch (tinggi rendahnya), kejelasan berbicara.

Dalam pencapaian penguasaan konsep IPA peserta didik, secara konsisten model pembelajaran POE lebih dapat memfasilitasi gaya belajar dibandingkan dengan model pembelajaran konvensional. Gaya belajar yang paling cocok difasilitasi dengan model pembelajaran POE adalah gaya belajar visual dan gaya belajar auditori, sedangkan model pembelajaran konvensional paling cocok diajarkan hanya dengan gaya belajar auditori. Kecenderungan gaya belajar visual yang lebih berperan dalam memperkuat interaksi karena sebagian besar pelaksanaan strategi pembelajaran yang dilaksanakan dalam penelitian ini banyak melibatkan indera penglihatan. Keadaan ini dapat dipahami karena jenis hasil belajar yang diukur ialah penguasaan konsep peserta didik yang banyak melibatkan indera penglihatan.

Nilai ketuntasan klasikal untuk kelas eksperimen dan kelas kontrol adalah $100 \%$. Sehingga dapat disimpulkan bahwa model pembelajaran POE dan model pembelajaran konvensional sama-sama efektif untuk meningkatkan penguasaan konsep IPA kelas VII SMPN 2 Kayangan karena nilai ketuntasan klasikalnya lebih dari $85 \%$ yang merupakan indikator keefektivan model pembelajaran.

\section{KESIMPULAN}

Berdasarkan hasil penelitian, analisis data dan pembahasan maka dapat diambil kesimpulan bahwa model pembelajaran POE dan konvensional keduaduanya dapat efektif meningkatkan penguasaan konsep IPA kelas VII di SMPN 2 Kayangan, akan tetapi peningkatan nilai rata-rata $\mathrm{N}$-gain untuk kelas eksperimen yang menggunakan model POE lebih tinggi (0.8) dibandingkan dengan kelas kontrol yang menggunakan model pembelajaran konvensional (0.6).

\section{DAFTAR PUSTAKA}

[1] Atriyanti, Y. dan Hadisaputro, S. (2015). Penerapan Model Pembelajaran POE Untuk Meningkatkan Ketercapaian Kompetensi Dasar Siswa. Chemistry In Education. 4 (1): 22526978.

[2] Crey, S. (1986). Cognitive Science and Science Education. American Psychologist. 41(10): 1123-1130.

[3] Jannah, S.N., Doyan, A dan Harjono, A.(2016). Pengaruh Model Pembelajaran Kooperatif Dengan Pendekatan Problem Posing Ditinjau Dari Pengetahuan Awal Terhadap Penguasaan
Konsep Fisika Siswa SMK. Journal Penelitian Pendidikan IPA. 2(1).

[4] Joyce, C., \& Predict, O. (2013). Explain (POE). 2006. Accessed online http://arb. nzcer. org. nz/strategies/poe. ph $p$.

[5] Maesyarah., Jufri, A.W dan Kusmiyati. (2015). Analisis Penguasaan Konsep dan Miskonsepsi Biologi dengan Teknik Modification Certainity of Response Index pada Siswa SMP Se-Kota Sumbawa Besar. Jurnal Pijar MIPA.10 (1): 1-6.

[6] Ndraka, T. (1985). Teori Metodologi Administrasi. Jakarta: Bina Aksara.

[7] Nuramelia. (2016). Pengaruh Model Pembelajaran POE (Predict-observe-Explain) Terhadap Keterampilan Proses Sains Siswa Pada Konsep Sistem Pencernaan. Universitas Islam Negeri Syarif Hidayatullah. Jakarta.

[8] Permendiknas, (2006). Peraturan Menteri Pendidikan Republik Indonesia Nomor 22 Tahun 2006 tentang Standar Isi untuk Satuan Pendidikan Dasar dan Menengah. Jakarta.

[9] Rahayu, S.A.T, Widodo dan Sudarmin. (2013). Pengembangan Perangkat Pembelajaran Model POE Berbantuan Media "I Am A Scientist". Innovative Journal of Curriculum And Educational Technology. 2(1): 129-133.

[10]Rahayu, P. (2015). Penerapan Strategi POE (Predict-Observe-explain) Dengan Metode Learning Journals Dalam Pembelajaran IPA Untuk Meningkatkan Pemahaman Konsep Dan Keterampilan Proses Sains. Universitas Negeri Semarang. Semarang.

[11] Susilawati, Susilawati dan Sridana, N. (2015). Pengaruh Model Pembelajaran Inkuiri Terbimbing Terhadap Penguasaan Konsep Sains Ditinjau Dari Kemampuan Awal Siswa. Journal Penelitian Pendidikan IPA. 1(2).

[12] Wahyuni, S., Kosim dan Gunawan. (2018). Pengembangan Perangkat Pembelajaran Fisika Berbasis Inkuiri Terbimbing Berbantuan Eksperimen Untuk Meningkatkan Penguasaan Konsep Siswa. J. Pijar MIPA. 4(2).

[13] Widyaningrum, R., Sarwanto dan Karyanto, P. (2013). Pengembangan Modul Berorientasi POE (Predict, Observe, Explain) Berwawasan Lingkungan Padamateri Pencemaran Untuk Meningkatkan Hasil Belajar Siswa. Bioedukasi. $6(1): 100-117$. 